\title{
WPS3593
}

\section{The Role of Factoring for Financing Small and Medium Enterprises}

\author{
Leora Klapper \\ Development Research Group \\ The World Bank \\ 1818 H Street, NW \\ Washington, DC 20433 \\ (202) 473-8738 \\ 1klapper@worldbank.org
}

\begin{abstract}
:
Around the world, factoring is a growing source of external financing for corporations and small and medium-size enterprises (SMEs). What is unique about factoring is that the credit provided by a lender is explicitly linked to the value of a supplier's accounts receivable and not the supplier's overall creditworthiness. Therefore, factoring allows high-risk suppliers to transfer their credit risk to their high-quality buyers. Factoring may be particularly useful in countries with weak judicial enforcement and imperfect records of upholding seniority claims, because receivables are sold, rather than collateralized, and factored receivables are not part of the estate of a bankrupt SME. Empirical tests find that factoring is larger in countries with greater economic development and growth and developed credit information bureaus. In addition, we find that creditor rights are not related to factoring. This paper also discusses "reverse factoring", which is a technology that can mitigate the problem of borrowers' informational opacity in business environments with weak information infrastructures if only receivables from highquality buyers are factored. We illustrate the case of the Nafin reverse factoring program in Mexico and highlight how the use of electronic channels and a supportive legal and regulatory environment can cut costs and provide greater SME services in emerging markets.
\end{abstract}

\section{World Bank Policy Research Working Paper 3593, May 2005}

The Policy Research Working Paper Series disseminates the findings of work in progress to encourage the exchange of ideas about development issues. An objective of the series is to get the findings out quickly, even if the presentations are less than fully polished. The papers carry the names of the authors and should be cited accordingly. The findings, interpretations, and conclusions expressed in this paper are entirely those of the authors. They do not necessarily represent the view of the World Bank, its Executive Directors, or the countries they represent. Policy Research Working Papers are available online at http://econ.worldbank.org.

Thanks to Marie-Renee Bakker, Thorsten Beck, Andrew Claster, Thomas Glaeessner, Ulrich Hess, Ashley Hubka, Peer Stein, Gregory Udell and Dimitri Vittas for helpful comments and to Tomoyuki Sho for outstanding research assistance. A special thanks to Gabriela Guillermo and Rafael Velasco at Nafin and Gamaliel Pascual at DBP for their generous assistance. The paper has also benefited from helpful conversation with Mexican buyers, suppliers and lenders that participate in the Nafin program. 


\section{Introduction}

A challenge for many small businesses is access to financing. In particular, many firms find it difficult to finance their production cycle, since after goods are delivered most buyers demand 30 to 90 days to pay. For this duration, sellers issue an invoice, recorded for the buyer as an account payable and for the seller as an account receivable, which is an illiquid asset for the seller until payment is received. Factoring is a type of supplier financing in which firms sell their credit-worthy accounts receivable at a discount (equal to interest plus service fees) and receive immediate cash. Factoring is not a loan and there are no additional liabilities on the firm's balance sheet, although it provides working capital financing. In addition, most factoring is done "without recourse", meaning that the factor that purchases the receivables assumes the credit risk for the buyer's ability to pay. Hence, factoring is a comprehensive financial service that includes credit protection, accounts receivable bookkeeping, collection services and financing.

Factoring is used in developed and developing countries around the world. In 2004, total worldwide factoring volume was over US\$ 860 billion, as the result of an impressive growth rate of $88 \%$ since 1998. In some developed economies such as the United States, its importance as a primary source of working capital finance tends to be concentrated in selected industries. In other developed economies such as Italy, however, its importance as a primary source of working capital appears to be much more widespread. As shown in Table 2, factoring is starting to emerge as a major source of financing in developing economies. 
The global pattern of factoring suggests that it may have an advantage compared to other types of lending, such as loans collateralized by fixed assets, under certain conditions. Factoring appears to be a powerful tool in providing financing to high-risk informationally opaque borrowers. Its key virtue is that underwriting in factoring is based on the risk of the accounts receivable themselves rather than the risk of the borrower. For example, factoring may be particularly well suited for financing receivables from large or foreign firms when those receivables are obligations of buyers who are more creditworthy than the seller itself.

Factoring may also be particularly important in financial systems with weak commercial laws and enforcement. Like traditional forms of commercial lending, factoring provides small and medium enterprises (SMEs) with working capital financing. However, unlike traditional forms of working capital financing, factoring involves the outright purchase of the accounts receivable by the factor, rather than the collateralization of a loan. The virtue of factoring in a weak business environment is that the factored receivables are removed from the bankruptcy estate of the borrower and become the property of the factor.

Empirical tests confirm these hypotheses. Using a sample of factoring turnover as a percentage of GDP for 48 countries around the world, we find that legal efficiency and creditor rights are not significant predictors of factoring. However, we find that access to historical credit information, which is necessary to access the credit risk of factoring transactions and enforce factoring arrangements, does matter. We also find weak evidence that factoring is relatively larger in countries with weak contract enforcement, which suggests that factoring may substitute for collateralized lending. We conclude 
with a discussion of the Nafin factoring program in Mexico, which is an example of "reverse factoring", a factoring technology can succeed in weak business environment.

\section{The Mechanics of Factoring}

In factoring, the underlying assets are the seller's accounts receivable, which are purchased by the factor at a discount. The remaining balance is paid to the seller when the receivables are paid to the factor, less interest and service fees. For example, most factors offer sellers financing up to $70 \%$ of the value of an account receivable and pay the remaining 30\% - less interest and service fees - when payment is received from the buyer. In general, financing is linked on a formula basis to the value of the underlying assets, e.g., the amount of available financing is continuously updated to equal a percentage of available receivables.

An important feature of the factoring relationship is that a factor will typically advance less than $100 \%$ of the face value of the receivable even though it takes ownership of the entire receivable. The difference between this advance amount and the invoice amount (adjusted for any netting effects such as sales rebates) creates a reserve held by the factor. This reserve will be used to cover any deficiencies in the payment of the related invoice. ${ }^{1}$ Thus, even in non-recourse factoring there is risk sharing between the factor and the client in the form of this reserve account.

Factoring can be done either on a "non-recourse" or "recourse" basis against the factor's client (the sellers). In non-recourse factoring, the lender not only assumes title to

\footnotetext{
${ }^{1}$ The reserve account represents a liability of the factor to its client. In effect, the client has extended contingent credit to the factor, which exposes the client to risk. As a result, if the factor becomes insolvent the client will become a general creditor of the factor and will be exposed to a potential loss up to the amount of the reserve. Thus, from the client's perspective the reputation and creditworthiness of the factor may be an important consideration.
} 
the accounts, but also assumes most of the default risk because the factor does not have recourse against the supplier if the accounts default. Under recourse factoring, on the other hand, the factor has a claim (i.e., recourse) against its client (the "borrower") for any account payment deficiency. Therefore, losses occur only if the underlying accounts default and the borrower cannot make up the deficiency. In developed countries it appears that factoring is more frequently done on a non-recourse basis. In Italy, for example, $69 \%$ of all factoring is done on a non-recourse basis (Muschella 2003). Similarly, a study of publicly traded firms in the U.S. found that $73 \%$ of firms factored their receivables on a non-recourse basis, but that both sellers with poorer quality receivables and sellers who, themselves, were higher quality were more likely to factor with recourse (Sopranzetti 1998). Since in emerging markets it is often problematic to assess the default risk of the underlying accounts, most factoring is done on a recourse basis. $^{2}$

In addition, factoring can be done on either a notification or non-notification basis. Notification means that the buyers are notified that their accounts (i.e., their payables) have been sold to a factor. Under notification factoring, the buyers typically furnish the factor with delivery receipts, an assignment of the accounts and duplicate invoices prepared in a form that indicates clearly to the supplier that their account has been purchased by the factor.

Factoring can be viewed as a bundle of activities. In addition to the financing component, factors typically provide two other complementary services to their clients: credit services and collection services. The credit services involve assessing the

\footnotetext{
${ }^{2}$ An exception is the factoring of foreign receivables in some emerging markets, such as Eastern Europe, which typically also involve some form of credit insurance.
} 
creditworthiness of the borrower's customers whose accounts the factor will purchase. Factors typically base this assessment on a combination of their own proprietary data and publicly available data on account payment performance. The collection services involve the activities associated with collecting delinquent accounts and minimizing the losses associated with these accounts. This includes notifying a buyer that an account is delinquent (i.e., past due) and pursuing collection through the judicial system. Factoring allows SMEs to effectively outsource their credit and collection functions to their factor. This represents another important distinction between factors and traditional commercial lenders.

These credit and collection services are often especially important for receivables from buyers located overseas. For example, "export factoring", the sale of foreign receivables, can facilitate and reduce the risk of international sales by collecting foreign accounts receivables. The factor is also required to do a credit check on the foreign customer before agreeing to purchase the receivable, so the approval of a factoring arrangement also sends an important signal to the seller before entering a business relationship. This can facilitate the expansion of sales to overseas markets.

For example, a firm in a developing country sells its goods to a firms in a developed country, which demands 60 days credit. The seller's factor will typically contact a factor in the buyer's home country (via Factor Chain International, a worldwide association of factoring companies) who will do a credit check on the buyer. If the buyer is approved, the seller's factor will pay the seller $70 \%$ of the face value of the receivable, and the factor in the buyer's country, for a fee, will take on the responsibility of collecting the amount due from the buyer. This setup allows firms in emerging markets 
to sell their goods overseas without facing the difficulties of overseas collections. In addition, the factor in the buyer's country must conduct a credit check before agreeing to factor the buyer, which reduces the sellers need to do due diligence on potential buyers. Because the trade credit extended by the seller can be easily converted into cash, the seller is able to offer more competitive terms to its customers. Finally, the seller is able to improve its own risk management, by reducing its credit and exchange rate risks.

\section{The Benefits and Challenges to Factoring in Emerging Markets}

Factoring is quite distinct from traditional forms of commercial lending where credit is primarily underwritten based on the creditworthiness of the borrower rather than the value of the borrower's underlying assets. In a traditional lending relationship, the lender looks to collateral only as a secondary source of repayment. The primary source of repayment is the borrower itself and its viability as an ongoing entity. In the case of factoring, the borrower's viability and creditworthiness, though not irrelevant, are only of secondary underwriting importance.

In some countries, borrowers can use receivables as collateral for loans. The difference is that the lender secures the working capital assets as collateral, rather than taking legal ownership of the assets. Therefore, this type of financing requires good secured lending laws, electronic collateral registries, and quick and efficient judicial systems, which are often unavailable in developing countries. However, factoring only requires the legal environment to sell, or assign, accounts receivables. Factoring does not require good collateral laws or efficient judicial systems. 
Factoring is often used in middle-income countries. For instance, the average ratio of factoring to GDP is $1.01 \%$ in middle-income counties, versus an average ratio of credit to the private sector to GDP of 55.67\%. This compares to an average ratio of factoring to GDP is $2.56 \%$ in high-income counties, versus an average ratio of credit to the private sector to GDP of $104.05 \%$. One reason for the relative success of factoring in emerging markets is that in many countries SMEs are unable to access sufficient financing from the banking system, yet large domestic, foreign, and multinational firms have cheap access to domestic and foreign bank and public-debt financing. Therefore, SMEs often depend on their large customers and suppliers to provide them with working capital financing. This may be in the form of 30-day credit from suppliers, which is repaid when the final goods are sold, or cash advances from customers, which is settled when the final goods are delivered. In addition, firms in developed countries also often refuse to pay on receipt to firms in emerging markets since they want time to confirm the quality of the goods and know that it could be very difficult to receive a refund from firms in countries with slow judicial systems.

Evidence in previous literature finds that trade credit is used more in countries with greater barriers to SME financing. For example, recent work by Demirguc-Kunt and Maksimovic (2001) finds that in 39 countries around the world, trade credit use is higher relative to bank credit in countries with weak legal environments, which make bank contracts more difficult to write. Fisman and Love (2002) highlight the impact of inter-firm financing by showing that industries with higher dependence on trade credit financing exhibit higher rates of growth in countries with relatively weak financial institutions. Van Horen (2004) studies the use of trade credit in 39 countries and finds 
that trade credit is used as a competitive tool, particularly for small and young firms. Fisman and Raturi (2003) find that competition encourages trade credit provision in five African countries. McMillan and Woodruff (1999) study the use of trade credit in Vietnam and find that small firms are more likely to both grant and receive trade credit than large firms. This evidence suggests that small firms in emerging markets generally provide trade credit and hold illiquid accounts receivable on their balance sheets.

The challenge faced by many SMEs in emerging markets is how to convert their accounts receivable to creditworthy customers into working capital financing. A bank loan secured by accounts receivable, which is the primary source of SME financing in the U.S., is often unavailable in emerging markets. First, it requires the lender to be able to file a lien against all business assets of the firm. For example, in the US the Uniform Commercial Code (UCC) Section 9 allows banks to secure "all current and future inventory, receivables, and cash flow" of a firm. Furthermore, this type of financing requires sophisticated technology and comprehensive credit information on firms. For instance, receivable lenders in the U.S and U.K. generally depend on "electronic ledgers", which allow firms to input all receivable information on-line along with their customers' Dunn \& Bradstreet (D\&B) ID numbers. The electronic ledger automatically receives the $\mathrm{D} \& \mathrm{~B}$ rating for each customer, which is a credit score calculated by $\mathrm{D} \& \mathrm{~B}$ based on the firms' current and expected future performance, and the receivables are instantaneously accepted or rejected as collateral. In the case of approval, the borrower's credit line is automatically increased to reflect the new receivables. However, most developing countries do not have laws allowing lenders to secure "intangible/ floating" assets and do not have judicial systems that are sufficiently quick and efficient to enforce 
such contracts. Furthermore, most emerging markets do not have the technological infrastructure or access to commercial credit information necessary to allow this type of financing.

For example, weaknesses in the business environment in the new EU-accession and transition countries gives factoring some key advantages over other lending products and has contributed to its growth in the region. There are several characteristics of factoring that may give it an edge in Eastern Europe. First, factoring removes receivables from the borrower's estate in bankruptcy, which may be particularly important if the judicial system is less developed or inefficient. Both of these conditions likely apply to most countries in Eastern Europe, as confirmed by the World Bank's Insolvency and Creditor Rights ROSC reports (Reports on Observance of Standards and Codes) for selected countries in the region. ${ }^{3}$ Second, factoring is a type of asset-based financing that has a distinct advantage in providing funding to higher risk and informationally opaque firms, especially SMEs. This is particularly relevant in transition countries whose private sectors are young and continuing to develop and expand in order to catch up to Western Europe. Furthermore, weak accounting standards and a shortage of audited financial statements is characteristic of the region. Factors can base their lending decision primarily on the condition of the underlying accounts (buyers) rather than the creditworthiness of their SME customers (suppliers).

There are also a number of additional tax, legal, and regulatory challenges to factoring in many developing countries. For instance, the tax treatment of factoring transactions often makes factoring prohibitively expensive. For example, some countries

\footnotetext{
${ }^{3}$ For country-level Insolvency and Creditor Rights ROSC reports, see: http://www.worldbank.org/ifa/rosc.html.
} 
that allow interest payments from banks to be tax deductible do not apply the same deduction to the interest on factoring arrangements, VAT taxes may be charged on the entire transaction (not just the service fee), and stamp taxes may be applied to each factored receivables. Factoring companies that do not take deposits are sometimes subject to burdensome and costly prudential regulation. In addition, capital controls may prevent non-banks from holding foreign currency accounts for cross-border assignments.

The legal and judicial environment may also play a critical role in determining the success of factoring. A key legal issue is whether a financial system's commercial law recognizes factoring as a sale and purchase. If it does, then creditor rights and enforcement of loan contracts diminish in importance for factoring because factors are not creditors. That is, if a firm becomes bankrupt, its factored receivables would not be part of the bankruptcy estate because they are the property of the factor, not the property of the bankrupt firm. However, creditor rights and contract enforcement are not entirely irrelevant to factors, even in non-recourse factoring arrangements, since they describe the environment under which the factor engages in its collection activities, which might affect the expected costs and efficiency of factoring. Another issue is whether a country has a Factoring Act or a reference in the law (or civil code), which legally recognizes factoring as a financial service. This recognition serves multiple purposes. It serves to clarify the nature of the transaction itself. For example, a Factoring Act explicitly dictates how judges must rule towards factors in the case of default of sellers or customers. It also tends to legitimize the factoring industry. For instance, in a sample of Central European countries, factoring (as a percentage of GDP) is higher in countries with Factoring Acts, although the development of such Acts may in part be in response to 
the development of, and pressures from, domestic factors. However, the indication is that a supportive legal and regulatory environment encourages the factoring industry to grow.

A weak information infrastructure may also be problematic for factors. The general lack of data on payment performance, such as the kind of information that is collected by public or private credit bureaus or by factors themselves, can discourage factoring. Since the credit risk of the transaction is the aggregate credit risk of all the supplier's customers, the cost and time required to collect information on many customers may discourage factoring in countries with weak credit information.

Finally, an advantage to factoring is that it's generally linked on a formula basis to the value of the underlying assets, which allows quick credit approval and disbursement. However, this depends on a good technology infrastructure and supporting electronic security laws that allow the electronic sale and transfer of electronic securities (accounts receivable). Furthermore, there must be a supportive regulatory environment for electronic security, so that factors and borrowers are assured that their transactions are confidential and secure. As discussed in the following section, the success of reverse factoring requires a legal environment that facilitates safe and easy electronic transactions. ${ }^{4}$

\section{The Determinants of Factoring}

In this section we test what country-level characteristics ae associated with a greater use of factoring. We use a 10-year panel dataset on total factoring turnover from Factor Chain International (2005) for 48 countries from 1993 to 2003. The data include

\footnotetext{
${ }^{4}$ For additional information see Glaessner, Kellermann, and McNevin (2002) and Claesssens, Glaessner and Klingbiel (2001).
} 
25 high-income and 23 middle-income countries. Since some countries did not start offering factoring services (or collecting aggregate measures) until after 1994, we use an unbalanced panel of 479 observations. Complete definitions of all variables are shown in Table 1 and summary statistics, by country, are shown in Tables 2 and 3. We calculate our dependent variable as the ratio of total factoring turnover to GDP. The average factoring ratio for the countries in our sample is $1.81 \%$

We test the hypothesis that there is a relation between factoring and local macroeconomic and business environment variables. As discussed in the previous section, ordinary factoring requires comprehensive credit information on all buyers and a legal environment that supports the sale of accounts receivables and the enforcement of factoring contracts. ${ }^{5} \mathrm{We}$ also expect that firms have larger sales and a greater volume of receivables to factor when the economy is healthy and growing, so that factoring should be positively related to real GDP and GDP growth. The relation between factoring and measures of bank credit is less clear: On the one hand, factoring services may be provided as a complement to banking services in countries with overall financial development, while on the other hand, factoring may substitute for bank financing in countries with less developed banking sectors.

To test these hypotheses, we include as our explanatory variables measures of macroeconomic development and the strength of the business environment. First, we include the 1-year lagged value of logged real GDP per capita $\left(\right.$ LGDPPC $\left._{t-1}\right)$ as a broad measure of development. Next, we include the 1-year lagged value of the 1-year growth rate of GDP as an indicator of economic growth $\left(\mathrm{GDPG}_{\mathrm{t}-1)}\right.$. Finally, we include the 1-

\footnotetext{
${ }^{5}$ Cross-country data is not available on the relative tax treatment of factoring or whether the law explicitly addresses factoring transactions.
} 
year lagged value of the ratio of credit to the private sector to GDP as a measure of credit availability (DC_GDP $\left.\mathrm{D}_{\mathrm{t}-1}\right)$. As shown in Table 4, these macroeconomic indicators are highly correlated. Therefore, we try alternative specifications and find that our results are robust to the exclusion of the ratio of credit to the private sector to GDP.

Our next set of explanatory variables includes indicators of the business and legal environment. First, we include the "Credit information index" (CreditInfo) from the World Bank's Doing Business Indicators, which measures the scope, access and quality of credit information available through either public or private bureaus. We expect factoring to be larger in countries with quick and comprehensive credit information on many buyers. Next, we include "Creditor Rights" (CreditorRts), which is an index aggregating four indicators of creditor rights from Djankov, McLiesh, and Shleifer (2005). ${ }^{6}$ We also include from the World Bank's Doing Business Indicators the "Cost of enforcing contracts as a \% of debt" (Enforce_Debt), which measures the cost of going through court procedures as a percentage of the debt value (a higher value indicates a weaker contract environment). It is difficult to predict the sign of these two variables, since on the one hand, factoring can substitute for collateralized lending in countries with weak collateral laws and contract enforcement (since the receivables are sold, rather than collateralized), but on the other hand, factoring requires strong creditor rights for the factor to collect from the buyer in the case of default.

Our regression results are shown in Table 5. In column 1 we include country fixed effects and in all columns (except column 6) we include year fixed effects. Since our business environment variables are constant over time, in column 6 we use country

\footnotetext{
${ }^{6}$ Our results are robust to the substitution of creditors rights with the broader "Legal rights index", which is measures the degree to which collateral and bankruptcy laws facilitate lending (Doing Business, 2004).
} 
averages and test a cross-section of data. Since the legal and business environment variables are highly correlated (as shown in Table 4), we introduce our variables separately as well as in one regression model.

For all models we find that factoring is significantly larger in countries with greater economic development, as measured by GDP per capita. When we exclude country dummies, the 1-year growth of GDP is significant, suggesting that factoring is larger when the economy is growing and sales - and subsequently the amount of trade credit extended and receivable recorded - is larger.

Columns 3 to 6 show that factoring is more important in countries with better availability of credit information. This complements the findings in previous studies that private credit to GDP is higher in countries with better information sharing (Djankov, et al. 2005, Love and Mylenko 2003). Our results suggest that access to credit information increases not only the provision of bank credit, but greater access to financing from nonbank sources as well.

We also find weak evidence that factoring is larger in countries with weaker contract enforcement, which is consistent with our hypothesis that factoring may be a substitute for lending in countries where it is more difficult to write a debt contract, enforce collateral, and collect in the case of default. The advantage of factoring in this environment is that it involves the sale of receivables, which makes the factor the owner of future payments from buyers, rather than a creditor of the supplier. This critical difference between factoring and bank lending may also explain why we do not find a relation between creditor rights and factoring, although the relation between these 
variables and private credit has been found significant in previous studies (La Porta, et al, 1997).

To summarize, our results find that ordinary factoring is an important source of financing in countries with better availability of credit information and weaker contract enforcement. Access to credit information is a challenge, however, in many developing countries with privacy laws prohibiting the sharing of credit information or where banks choose not to share their customer information. In the next section we discuss an alternative form of factoring that may overcome this barrier to factoring and succeed in weak business environments.

\section{The Advantage of "Reverse Factoring"}

In ordinary factoring, a small firm sells its complete portfolio of receivables, from multiple buyers, to a single factor. Many factors will only purchase complete portfolios of receivables in order to diversify their risk to any one seller. In fact, many factors require sellers to have a minimum number of customers in order to reduce the exposure of the factor to one buyer - and to the seller's ability to repay from receipts from other buyers - in the case that a buyer defaults. However, this diversified portfolio approach requires factors to collect credit information and calculate the credit risk for many buyers.

Ordinary factoring has in general not been profitable in emerging markets. First, if good historical credit information in unavailable, then the factor takes on a large credit risk. For instance, in many emerging markets, the credit information bureau is incomplete (i.e. may not include small firms) or non-bank lenders, such as factors, are

prohibited from joining. Second, fraud is a big problem in this industry - bogus receivables, non-existing customers, etc. - and a weak legal environment and non- 
electronic business registries and credit bureaus make it more difficult to identify these problems. An alternative usually used in emerging markets is for the factor to buy receivables "with recourse", which means that the seller is accountable in the case that a buyer does not pay its invoice, and that the seller of the receivables retains the credit risk. However, this may not successfully reduce the factor's exposure to the credit risk of the seller's customers, since in the case of a customer's default, the seller may not have sufficient capital reserves to repay the factor.

One solution to these barriers to factoring is the technology often referred to as "Reverse Factoring". In this case, the lender purchases accounts receivables only from high-quality buyers (e.g. any receivable from a specific informationally transparent buyer). The factor only needs to collect credit information and calculate the credit risk for a few selected buyers (such as a large, internationally accredited firm). The main advantage of reverse factoring is that the credit risk is equal to the default risk of the high-quality customer, and not the risky SME. This arrangement allows creditors in developing countries to factor "without recourse" and provide low-risk loans to high-risk suppliers.

Reverse factoring may be particularly beneficial for SMEs for a number of reasons. First as previously discussed, ordinary factoring requires comprehensive credit information on all the borrower's customers, which may be particularly difficult and costly to determine for SMEs in countries with weak credit information systems. Second, reverse factoring make possible for firms to factor without recourse, which allows SMEs to transfer their credit risk and borrow on the credit risk of its creditworthy customers. This may allow firms to borrow greater amounts at lower costs. 
Another advantage of reverse factoring is that it provides benefits to lenders and buyers as well. In many countries factoring is offered by banks. In this case, factoring enables lenders to develop relationships with small firms (with high quality customers) without taking on additional risk. This may provide cross-selling opportunities and allows the lender to build a credit history on the small firm that may lead to additional lending (for fixed assets, for example). The large buyers may also benefit: by engineering a reverse factoring arrangement with a lender and providing its customers with working capital financing, the buyer may be able to negotiate better terms with its suppliers. For example, buyers may be able to extend the terms of their accounts payable from 30 to 60 days. In addition, the buyer benefits from outsourcing its own payables management (e.g. the buyer can send a payment to one lender rather than many small suppliers).

\section{The Nafin Factoring Program in Mexico}

As discussed in the previous section, ordinary factoring requires lenders to have timely and comprehensive credit information and suppliers to have sophisticated technology and management information systems (MIS). However, reverse factoring only requires complete credit information on one or more creditworthy firms. There are potentially advantages for all participants: For the factor, who benefits from low information costs and credit risk; for the (high-risk) seller, who benefits from access to short-term, working capital financing; and for the (creditworthy) buyer, who benefits from the ability to outsource its receivable management and negotiate better terms with its suppliers. 
A successful example of reverse factoring in a developing country is the case of the Nacional Financiera (Nafin) development bank in Mexico, which offers on-line factoring services to SME suppliers. ${ }^{7}$ The program is called "Cadenas Productivas", or "Productive Chains" program and works by creating "Chains" between "Big Buyers" and small suppliers. The Big Buyers are large, creditworthy firms that are low credit risk. The suppliers are typically small, risky firms who generally cannot access any financing from the formal banking sector. The Nafin program allows these small suppliers to use their receivables from Big Buyers to receive working capital financing, effectively transferring their credit risk to their high-quality customers to access more and cheaper financing.

What makes Nafin special is that it operates an electronic platform that provides on-line factoring services, which reduces costs and improves security. Over $98 \%$ of all services are provided electronically, which reduces time and labor costs. The electronic platform also allows all commercial banks to participate in the program, which gives national reach, via the internet, to regional banks. Nafin also uses the Internet and regional "contact centers" to market and provide services. Technology has allowed successful economies of scale - Nafin grew from a 2\% market share of factoring in 2001 to $60 \%$ of the market in 2004 .

There are a number of additional characteristics that make the Nafin program unique. For example, all factoring is done on a non-recourse basis, which lets small firms increase their cash holdings and improve their balance sheets. Also, Nafin has a "Multibank" approach, which allows lenders to compete to factor suppliers' receivables. In addition, Nafin pays for the costs associated with their electronic factoring platform and

\footnotetext{
${ }^{7}$ Additional information is available at www.nafin.com.
} 
all legal work, such as document transfers, preparing and signing documents, etc., so that banks charge only interest and not service fees. Nafin covers ts own cost with the interest that lenders pay for Nafin's refinancing capital or service fees.

Nafin was created by the Mexican government in 1934 as a state-owned development bank with the goal of providing commercial financing. It has 32 statebranch offices throughout the country. When a new government was elected in 2000, Nafin was given new management and direction with the goal to (1) use new technology to provide microenterprise and SME loans and (2) complement lending with greater training and technical assistance. The factoring program is integrated with the Mexican e-government model that aims to use the internet to provide quicker and cheaper government services. Nafin is primarily a second-tier development bank: About $90 \%$ of lending is done through refinanced bank loans and about $10 \%$ is made directly to borrowers (primarily public projects). About $80 \%$ of the second-tier business is currently the factoring of receivables of commercial firms. In Dec 2000, Nafin reported assets of $\$ 23.9$ billion and a deficit of $\$ 429$ million. In Dec 2003, Nafin reported assets of $\$ 26.75$ billion and a surplus of 13.23 million. Factoring has helped contribute to the turn-around in Nafin's balance sheet.

About $99 \%$ of registered firms in the formal economy - about 600,000 firms - are classified as small and micro enterprises. ${ }^{8}$ SMEs comprise $64 \%$ of employment and $42 \%$ of GDP. The typical Mexican SME receives $65 \%$ of its working capital from family savings and other personal funds, another $18 \%$ from friends and parents - and less than

\footnotetext{
${ }^{8}$ Microenterprises are defined as manufacturing firms with up to 30 employees and service firms with up to 20 employees. Small firms are defined as 31-100 employees in the manufacturing sector and 21-50 firms in the service sector and Medium firms are defined as 101-500 employees in the manufacturing sector and 51-100 firms in the service sector.
} 
$1 \%$ from banks (Kun 2002). The goal of Nafin was to target this segment of small firms with banking services.

Nafin has succeeded in providing financial services to Mexican SMEs. As of mid-2004, Nafin had established Productive Chains with 190 Big Buyers (about 45\% in the private sector) and more than 70,000 small and medium firms (out of a total of about 150,000 participating suppliers). About 20 domestic lenders are participating, including banks and independent finance companies. Nafin has extended over US\$ 9 billion in financing since the program's inception in September 2001 and has reached monthly factoring amounts of over US\$600,000. Nafin has brokered over 1.2 million transactions - $98 \%$ by SMEs - at a rate of about 4,000 operations per day.

The Nafin program offers a number of products. The main product offered is factoring service, as shown in Figure 1. Services are offered without recourse or any collateral or service fees, at a maximum interest rate of seven percentage points above the bank rate (five percentage points, on average), which is about eight percentage points below commercial bank rates. ${ }^{9}$ Importantly, the sale of receivables from the supplier and the transfer of funds to the supplier are done electronically, once the SME is registered on-line or on the phone and has an account with a bank or factor that has a relationship with the supplier's big buyer. The funds are transferred to the supplier's bank account, and the bank becomes the creditor (e.g. the buyer repays the bank directly). The Bank collects the loan amount when the buyer pays the supplier (in 30 to 90 days).

Nafin maintains an internet site with a dedicated page for each Big Buyer. Suppliers are grouped in "chains" to big buyers to whom they have a business

\footnotetext{
${ }^{9}$ Nafin plans to allow banks to compete with one another on the interest charged for factoring. For example, a good bank customer may receive preferential rates.
} 
relationship. Nafin also plays a critical role in handling the sale and delivery of electronic documents. The suppliers and Nafin sign a pre-agreement allowing the electronic sale and transfer of receivables. Additional contracts between the banks and buyers and Nafin define their obligations, such as the requirement for buyers to remit factored receivables to the banks directly.

Once a supplier delivers its goods and an invoice to the buyer, the buyer posts on its Nafin webpage a "documentos negociables", or "negotiable document", equal to the amount that Nafin should factor. In general, this is equal to $100 \%$ of the value of the receivable. ${ }^{10}$ Next, the supplier uses the internet to access its buyer's Nafin webpage and clicks its receivable. ${ }^{11}$ Any lender that has a relationship with the buyer and the supplier and is willing to factor the receivable will appear on the next screen, along with a quote for the interest rate at which it's willing to factor this specific receivable. ${ }^{12}$ To factor its receivable, the supplier clicks on a shown factor and the amount of its negotiable document less interest is transferred to its bank account. ${ }^{13}$ When the invoice is due, the buyer pays the factor directly.

Even though the buyers are high quality, a remaining risk to the factor is in the case of returns - if the buyer is unsatisfied with the quality of the goods or services received, they generally have the right to return the goods for a full refund within a certain number of days. However, factors are responsible to pay Nafin on the day the

\footnotetext{
${ }^{10}$ A buyer may choose to hold a "commercial reserve" for the case of returns, which is done by posting to its Nafin website a "negotiable document" less than $100 \%$ of the invoice. In this case the buyer is responsible to pay the difference to the supplier when the invoice is due.

${ }^{11}$ Factoring can also be executed by phone for no extra fee.

${ }^{12}$ An advantage of the multi-bank Nafin model is that other factors are available if the supplier's primary bank is unable to factor a receivable because it has reached its lending limit to that particular buyer.

${ }^{13}$ In most factoring arrangements the supplier receives a percentage of its invoice today and the remainder less interest when the buyer pays the factor. In comparison, the Nafin program generally pays the supplier $100 \%$ of its invoice, less interest today and the factor keeps the full amount paid by the buyer.
} 
invoice expires, regardless of whether the buyer pays the bank the full amount. ${ }^{14}$ Nafin and the buyers help banks reduce their losses in two ways: First, buyers must "invite" sellers to join their chain and participate in the program. Buyers generally require sellers to have a relationship of a minimum length and performance record before participating. Second, in the case of returns, the factor receives future receivable payments directly from the buyer and the buyer adjusts the amount of the negotiable documents on future receivable payments posted on the Nafin website by the amount of the receivables due to returns.

The Nafin factoring program is successful because it uses an electronic platform for cheaper and quicker transactions. All transactions are completed within 3 hours and money is credited to suppliers account by the close of business. This provides immediate liquidity to suppliers. The Nafin factoring program is also less expensive than commercial factoring because Nafin waives the service fee by paying the overhead and legal costs associated with maintaining the electronic platform and writing the contracts.

The Nafin factoring program has succeeded because of supporting electronic security laws. ${ }^{15}$ For example, in May 2000, the "Law of Conservation of Electronic Documents" was passed giving data messages the same legal validity as written documents, which is necessary for electronic factoring. In April 2003, the "Electronic Signature Law" was enacted, which allows secure transactions substituting electronic signatures for written signatures, which permits the receiver of a digital document to verify with certainty the identity of the sender. In January 2004, modifications to the

\footnotetext{
${ }^{14}$ As a result of this condition, Nafin has reported zero loses from factoring.

15 See AMECE (2004) for additional details on electronic security laws in Mexico and other countries.
} 
Federation Fiscal code included amendments necessary for electronic factoring, including digital certification. These laws allow secure and legally binding factoring transactions.

The second product, "Contract Financing", is shown in Figure 2. This provides financing u to $50 \%$ of confirmed contract orders from Big Buyers with Nafin supply chains, with no fees or collateral, and a fixed rate (generally seven percentage points above the bank rate). First, the supplier signs a contract with Nafin stipulating that (i) Nafin will provide a Line of Credit equal to up to $50 \%$ or the purchase order and that (ii) the supplier will factor its receivables to the lender when its goods are delivered. Once the supplier receives a contract order from a big buyer, Nafin provides a line of credit for up to $50 \%$ of the order at the bank rate $+7 \%$.

After the goods are delivered the buyer receives an invoice and posts a negotiable document to its Nafin website. Nafin factors the negotiable document and takes as payment the amount of the negotiable document equal to the outstanding line of credit plus interest, up to $100 \%$ of the negotiable document. ${ }^{16}$ The remainder is paid to the supplier less the interest paid on factoring, equal to the lower interest rate of the bank rate $+5 \%$. Nafin is paid directly by the buyer when the invoice becomes due. This funding allows creditors to buy raw materials to complete new orders. Nafin introduced this program in 2004 and as of July 2004, provides the financing directly to small suppliers and holds the future receivables until the buyer remits. However, it is the intent of Nafin to develop a track-record of profitability and low defaults rates with this program so that private lenders will participate (with Nafin financing).

\footnotetext{
${ }^{16}$ Since Nafin only factors up to $50 \%$ of purchas e orders, the Nafin loan would only equal $100 \%$ of the receivables in the case that the firm does not deliver its full order or some goods are returned.
} 
The third service is training, which includes on-line and attendance courses on accounting standards, how to apply for credit, business ethics, marketing, and strategy. ${ }^{17}$ SMEs are also offered discounts at affiliated university classes. About $70 \%$ of SMEs participated in some form of training.

The forth service is technical assistance, which offers participating suppliers email responses to e-mailed questions within 48 hours. Suppliers can also receive information on public-sector selling opportunities provided by Compranet, the Mexican government's e-procurement initiative. Nafin also has a call-center to answer questions and provide assistance with on-line transactions (for no extra fee). Suppliers that cannot access the internet can also use the call centers to do all transactions by phone, for no additional fee. The call center is also used to generate new business and has about 160 employees in three locations. Callers contact large buyers to form relationships. Buyers then provide Nafin with a list of all their suppliers, which Nafin calls to introduce the factoring product and collect information about the firm. This information is used to set up a credit profile that can later be used to set up banking and factoring relationships.

The Nafin program offers benefits to sellers, buyers, and lenders. For small suppliers, the Nafin factoring program reduces the borrowing and transaction costs of small suppliers. First, factoring offers working capital financing at favorable rates. Factoring provides instant liquidity, which allows businesses to grow with funds that were previously tied up in receivables. In addition, all interest charges are tax deductible. The Nafin program also has advantages over traditional factoring products. Since reverse factoring transfers the credit risk of the loan to the suppliers' high-quality buyers, Nafin can offer factoring without recourse to SMEs, even those without credit histories. This

${ }^{17}$ A complete list of courses is available at www.nafinsa.com. 
allows SMEs to increase their cash stock - and improve their balance sheets - without taking on additional debt. In addition, Nafin charges no commissions (to the seller) and offers capped interest rates. The competitive structure, which allows lenders to compete for suppliers' receivables, allows firms to pick their own lender. Second, factoring reduces transaction costs. Previously, many rural SMEs needed to travel to customers in the city to present bills, collect payments, pay suppliers, etc. By factoring its receivables, the supplier eliminates its collection costs by effectively outsourcing its receivable management.

Many suppliers have no other sources of financing. In discussions with suppliers, many reported that they had no external financing before receiving financing from Nafin and most depended on internal funds and credit from their own suppliers. In addition, suppliers stated that the Nafin financing is preferable to bank financing, since banks are slow to make credit decisions, would offer less credit, and charge higher rates. Some small firms reported that they had previously factored with other lenders, but at higher rates plus high service fees. Overall, suppliers commended the Nafin program.

For the Big Buyers, the benefit is that the lender provides receivables management and the buyer often develops stronger relationships with its suppliers. For instance, buyers decrease their administrative and processing costs by effectively outsourcing their payment department, e.g. the buyer writes one check to a bank rather than to hundreds of suppliers. By providing its suppliers with working capital financing, buyers can also improve their reputation and relationship with suppliers. For example, buyers can often negotiate better terms with suppliers, e.g. extend payment terms from 30 to 60 or 90 days. Participating in the Nafin program can also help the development of 
suppliers and the growth of the SME sector, which can lead to increases in competition and improvements in the quality of goods.

In general, buyers require their suppliers to meet three criteria in order to be "invited" to join their chains. First, the firm must have been a supplier for at least six months and have been fully compliant with all purchase orders. Second, the supplier must have completed at least one purchase order per month (i.e. are a regular supplier). Third, the buyers must have had negligible returns and losses.

For the factors, which are mostly banks, factoring is a way to develop new relationships with suppliers - banks can use factoring to build a credit history on firms, including information on their cash, accounts receivable and inventory turnover, and cross-sell other products such as credit cards, truck financing, payroll, etc. In addition, because reverse factoring only includes high quality receivables, banks can increase their operations without increasing their risk.

Banks also have incentive to participate in the Nafin program, since Nafin provides low-cost financing. Most banks refinance their factoring activities with Nafin, in which case the bank earns the spread between what the suppliers pay and the Nafin rates. Some larger banks with cheaper sources of funding use their own funds and pay Nafin from 42 to 100 basis points commission. However, about $99.6 \%$ of factoring is done with Nafin financing. Five banks and factoring companies represent $54 \%$ of all factoring transactions: Banorte, Mifel, Interacciones, Heller (GE Capital) and Bital (HSBC). The Nafin platform also allows low transaction costs. The E-platform eliminates the need to physically move documents, which is a large expense in off-line factoring. 
Another advantage is that for regulatory purposes, banks can use lower risk weights on factored transactions; e.g. if the factoring is done without recourse, banks can use the risk of the buyer rather than the higher risk of the supplier. This is an important reason that banks will lend to small and risky customers only in factoring arrangements. In addition, an advantage of the Nafin platform is that it prevents fraud, which is systemic in the factoring business in the U.S. and other developed countries. Since the buyer enters the receivables (not the customers), the seller cannot submit fraudulent receivables. Since the bank is paid directly by the buyer, suppliers cannot embezzle the proceeds.

In the future, Nafin can also play a role to securitize receivables. For example, a security backed by Walmart receivables might be an attractive security, equal to the credit risk of Walmart. Nafin could play an important coordination role bundling receivables of one large buyer across lenders, since no one lender has a large enough portfolio to securitize independently. Nafin is also committed to working toward the development of capital markets in order for small and midsize non-bank (non-deposit taking) financial intermediaries to participate. For example, independent leasing and factoring companies generally raise capital on the public debt and equity markets (e.g. in the U.S. NBFIs are the largest issuers of commercial paper).

There are a number of lessons to be learned from the Nafin program. The Mexican economy has improved the past few years, as the result of macro stability and the continuing recovery of the banking sector from the 1990s crises, and banks are aggressively entering SME lending. However, factoring remains the cheapest form of financing for small suppliers in Mexico and most suppliers that participate in the Nafin 
program have no other sources of formal financing. The success of the Nafin program spotlights the role of factoring as an important source of working capital financing.

The success of the Nafin program highlights how the use of electronic channels can cut costs and provide greater SME services. The Nafin factoring program is used as a model in Mexico for the automation of other government agencies and service providers. Advances in technology can reduce the costs of lending that can allow banks to lend at lower margins, which make borrowing feasible for small firms. On-line banking services also allow lenders to penetrate rural areas without banks and provide incentive for firms in the informal sector to register and take advantage of financing opportunities. The success of the Nafin program depends on the legal and regulatory support offered in Electronic Signature and Security laws that should be a model for other developing countries.

Nafin has entered an agreement with a development bank in Venezuela to develop a similar product and the model is being considered for replication in other Latin American countries such as Argentina, Chile, Costa Rica, El Salvador, and Nicaragua. Like Nafin in Mexico, this model is also an intriguing way to invigorate, redefine and refocus a state-owned development bank. The Nafin program has shown that in addition to financing, a development bank can also be utilized to provide training and information. Factoring is an ideal source of financing in countries with small, risky suppliers and large and foreign buyers. However, successful factoring programs require government support in setting up a legal and regulatory environment that allows a secure and electronic sale of receivables. 


\section{Conclusion}

Around the world, factoring is a growing source of external financing for large corporations and SMEs. What is unique about factoring is that the credit provided by a lender is explicitly linked on a formula basis to the value of a supplier's accounts receivable and not the supplier's overall creditworthiness. Therefore, factoring allows high-risk suppliers to transfer their credit risk to their high-quality buyers. Similarly, in high-risk business environments, e.g. poor credit information infrastructures, only highquality firms can access financing and factoring may be the only source of financing for high-risk, informationally opaque firms. Factoring may be particularly useful in countries with weak contract enforcement, inefficient bankruptcy systems, and imperfect records of upholding seniority claims, because receivables factored without recourse are not part of the estate of a bankrupt SME. Factoring can also mitigate the problem of borrowers' informational opacity in business environments with weak information infrastructures if only receivables from high-quality buyers are factored.

Empirical tests show the importance of economic development and growth for the provision of factoring services. In addition, our tests highlight the importance of good credit information for the success of factoring. We also find weak evidence that factoring is larger in countries with weak contract enforcement. For instance, because ordinary factoring requires historical credit information on a large number of buyers, its success depends on access to quick and comprehensive credit information.

Our paper also suggests "reverse factoring" as an alternative factoring technology in countries with poor credit information. An example of reverse factoring is the Nafin factoring program, which highlights how the use of electronic channels can cut costs and 
provide greater SME services in emerging markets. By creating "chains" of small suppliers and big buyers, Nafin can offer low-cost factoring without recourse, which is an important source of financing and improves the balance sheet of small firms. The success of the Nafin program depends on the legal and regulatory support offered in Electronic Signature and Security laws that should be a model for other developing countries. 


\section{$\underline{\text { References }}$}

Bakker, Marie-Renee, Leora Klapper and Gregory Udell, 2004, "The Role of Factoring in Commercial Finance and the Case of Eastern Europe", World Bank Working Paper No. 3342.

Djankov, Simeon, Caralee McLiesh, and Andrei Shleifer, 2005, Private credit in 129 countries, NBER working paper 11078.

Fisman, Ray and M. Rature, 2003, Does competition encourage credit provision? Evidence from African trade credit relationships, Review of Economics and Statistics, forthcoming.

Glaessner, Thomas, Tom Kellermann, and Valerie McNevin, 2002, Electronic security: Risk mitigation in financial transactions, World Bank Policy Research Working Paper.

Glaessner, Thomas and Zeynep Kantur, 2004, Two Case studies on electronic distribution of government securities", World Bank Policy Research Working Paper.

Hess, Ulrich, Kaspar Richter and Andrea Stoppa, 2002, Weather risk management for agriculture and agri-business in developing counties, in Dischel, Robert, ed. Climate Risk and the Weather Market, Financial Risk Management with Weather Hedges, London: RiskBooks.

Love, Inessa and Nataliya Mylenko, 2003, Credit reporting and financing constraints, World Bank Policy Research Working Paper 3142, October.

La Porta, Rafael, Florencio Lopez-de-Silanes, Andrei Shleifer, and Robert Vishny, 1998, Legal determinants of external finance, Journal of Finance 52, 1131-1150.

McMillan J and Christopher Woodruff, 1999, Interfirm relationships and informal credit in Vietnam, Quarterly Journal of Economics 114, 1285-1320.

Stijn Claessens, Thomas Glaessner, Daniela Klingebiel, 2001, "E-Finance in Emerging Markets: Is Leapfrogging Possible?", World Bank Policy Research Working Paper.

Van Horen, Neeltje, 2004, Do firms use trade credit as a competitiveness tool? Evidence from developing countries, World Bank mimeo. 
Table 1: Descriptions of the Variables

\begin{tabular}{|l|l|c|}
\hline \multicolumn{1}{|c|}{$\begin{array}{c}\text { Variable } \\
\text { Name }\end{array}$} & \multicolumn{1}{|c|}{ Description } & Mean \\
\hline Fact_GDP & $\begin{array}{l}\text { Total factoring turnover as a percentage of nominal } \\
\text { GDP. Source: Factor Chain International (factoring } \\
\text { turnover) and World Bank (GDP). }\end{array}$ & 1.68 \\
\hline LGDPPC $_{\mathrm{t}-1}$ & GDP per capita, lagged 1 year. Source: World Bank. & 8.99 \\
\hline GDPG1 $_{\mathrm{t}-1}$ & $\begin{array}{l}\text { 1-Year growth rate of GDP, lagged 1 year (percent). } \\
\text { Source: World Bank. }\end{array}$ & 3.46 \\
\hline DC_GDP $_{\mathrm{t}-1}$ & $\begin{array}{l}\text { Domestic credit to the private sector as a percentage of } \\
\text { GDP, lagged 1 year. Source: World Bank. }\end{array}$ & 74.94 \\
\hline CreditorRts & $\begin{array}{l}\text { An index aggregating four creditor rights: restrictions } \\
\text { on reorganization, no automatic stay on assets, if } \\
\text { secured creditors are paid first, and if management } \\
\text { does not stay during reorganization. Source: Djankov, } \\
\text { McLiesh, and Shleifer, 2004. }\end{array}$ & 1.96 \\
\hline CreditInfo & $\begin{array}{l}\text { "Credit information index", which measures the scope, } \\
\text { access and quality of credit information available } \\
\text { through either public or private bureaus. } \underline{\text { Source: }} \\
\text { Doing Business Indicators. }\end{array}$ & 4.18 \\
\hline Enforce_Debt & $\begin{array}{l}\text { "Cost of enforcing contracts as a \% of Debt", which } \\
\text { measures the official cost of going through court } \\
\text { procedures for debt recovery, as a percentage of the } \\
\text { debt value. Source: Doing Business Indicators. }\end{array}$ & 17.35 \\
\hline
\end{tabular}


Table 2: Average Factoring Turnover By Country, 1994-2003 (in Millions of EUR)

See Table 1 for variable definitions.

\begin{tabular}{|c|c|c|c|}
\hline Countries & $\begin{array}{l}\text { Factoring Turnover } \\
\text { (millions Euro) }\end{array}$ & $\begin{array}{c}\text { Factoring as a } \\
\text { Percentage of GDP } \\
\text { (Fact_GDP) }\end{array}$ & $\begin{array}{l}\text { 3-Yr Growth Rate of } \\
\text { Factoring Turnover } \\
(2000 \text { to 2003) }\end{array}$ \\
\hline Argentina & 675.60 & 0.25 & $-95.92 \%$ \\
\hline Australia & $5,690.80$ & 1.37 & $87.38 \%$ \\
\hline Austria & $2,111.30$ & 1.00 & $28.88 \%$ \\
\hline Belgium & $6,938.10$ & 2.75 & $43.75 \%$ \\
\hline Brazil & $8,662.10$ & 1.54 & $0.23 \%$ \\
\hline Canada & $2,425.50$ & 0.37 & $40.12 \%$ \\
\hline Chile & $2,247.80$ & 3.19 & $32.08 \%$ \\
\hline China & 630.80 & 0.05 & $1,145.28 \%$ \\
\hline Costa Rica & 124.90 & 0.78 & $-28.29 \%$ \\
\hline Czech Republic & 876.10 & 1.43 & $87.06 \%$ \\
\hline Denmark & $3,733.70$ & 2.16 & $37.53 \%$ \\
\hline Finland & $5,826.10$ & 4.52 & $23.56 \%$ \\
\hline France & $48,650.60$ & 3.35 & $39.56 \%$ \\
\hline Germany & $21,936.50$ & 1.04 & $49.39 \%$ \\
\hline Greece & $1,238.20$ & 0.93 & $145.33 \%$ \\
\hline Hong Kong & $1,772.00$ & 1.10 & $35.42 \%$ \\
\hline Hungary & 359.70 & 0.62 & $231.98 \%$ \\
\hline India & 549.30 & 0.11 & $243.62 \%$ \\
\hline Indonesia & 762.30 & 0.36 & $-66.67 \%$ \\
\hline Ireland & $5,332.70$ & 5.48 & $36.15 \%$ \\
\hline Israel & 190.40 & 0.18 & $-58.70 \%$ \\
\hline Italy & $89,005.90$ & 7.56 & $20.46 \%$ \\
\hline Japan & $44,423.20$ & 1.01 & $3.55 \%$ \\
\hline Malaysia & $1,247.10$ & 1.39 & $22.74 \%$ \\
\hline Mexico & $5,073.30$ & 1.09 & $-9.84 \%$ \\
\hline Morocco & 111.70 & 0.31 & $255.56 \%$ \\
\hline Netherlands & $16,812.40$ & 4.19 & $10.06 \%$ \\
\hline New Zealand & 213.70 & 0.36 & $163.00 \%$ \\
\hline Norway & $5,066.90$ & 3.05 & $53.73 \%$ \\
\hline Oman & 14.00 & 0.08 & $-66.67 \%$ \\
\hline Panama & 101.83 & 0.83 & $-27.27 \%$ \\
\hline Poland & $1,220.70$ & 0.66 & $23.74 \%$ \\
\hline Portugal & $7,103.20$ & 6.12 & $35.42 \%$ \\
\hline Romania & 66.00 & 0.15 & $275.00 \%$ \\
\hline Singapore & $2,151.40$ & 2.49 & $15.95 \%$ \\
\hline Slovakia & 188.60 & 0.83 & $140.00 \%$ \\
\hline Slovenia & 48.10 & 0.22 & $161.54 \%$ \\
\hline South Africa & 4467.90 & 3.40 & $-1.44 \%$ \\
\hline South Korea & $10,849.30$ & 2.34 & $-66.96 \%$ \\
\hline Spain & $16,072.40$ & 2.52 & $92.24 \%$ \\
\hline Sweden & $8,050.40$ & 3.21 & $-11.05 \%$ \\
\hline Switzerland & $1,227.20$ & 0.46 & $16.46 \%$ \\
\hline Taiwan & $3,718.40$ & 0.82 & $338.36 \%$ \\
\hline Thailand & $1,136.40$ & 0.83 & $12.38 \%$ \\
\hline Tunisia & 120.17 & 0.56 & $250.00 \%$ \\
\hline Turkey & $3,634.20$ & 1.94 & $-16.59 \%$ \\
\hline United Kingdom & $99,825.00$ & 6.96 & $29.89 \%$ \\
\hline USA & $77,722.10$ & 0.86 & $-21.09 \%$ \\
\hline Average middle-income countries & $1,876.87$ & 1.01 & 1.09 \\
\hline Average high-income countries & $19,089.52$ & 2.56 & 0.50 \\
\hline Average (total) & $10,841.79$ & 1.81 & 0.78 \\
\hline
\end{tabular}


Table 3: Average Macroeconomic, Legal and Business Enviornment Variables, By Country

See Table 1 for variable definitions.

\begin{tabular}{|c|c|c|c|c|c|c|}
\hline Country & LGDPPC $_{t-1}$ & GDPPC $_{t-1}$ & DC_GDP $_{t-1}$ & CreditorRts & CreditInfo & Enforce_Debt \\
\hline Argentina & 8.97 & 0.11 & 21.27 & 1 & 6 & 15 \\
\hline Australia & 10.01 & 3.83 & 78.93 & 3 & 5 & 14.4 \\
\hline Austria & 10.36 & 2.19 & 100.3 & 3 & 5 & 9.8 \\
\hline Belgium & 10.28 & 2.31 & 77.43 & 2 & 6 & 6.2 \\
\hline Brazil & 8.41 & 2.7 & 37.36 & 1 & 6 & 15.5 \\
\hline Canada & 9.97 & 3.59 & 80.82 & 1 & 5 & 12 \\
\hline Chile & 8.52 & 4.81 & 60.75 & 2 & 6 & 10.4 \\
\hline China & 6.58 & 8.88 & 110.94 & 2 & 3 & 25.5 \\
\hline Costa Rica & 8.2 & 4.18 & 19.22 & 1 & 5 & 41.2 \\
\hline Czech Republic & 8.57 & 2.21 & 62.27 & 3 & 5 & 9.6 \\
\hline Denmark & 10.51 & 2.8 & 69.31 & 3 & 4 & 6.6 \\
\hline Finland & 10.26 & 3.79 & 58.06 & 1 & 4 & 7.2 \\
\hline France & 10.26 & 2.27 & 85.81 & 0 & 3 & 11.7 \\
\hline Germany & 10.35 & 1.54 & 113.61 & 3 & 6 & 10.5 \\
\hline Greece & 9.42 & 3.25 & 43.45 & 1 & 4 & 12.7 \\
\hline Hong Kong & 10.08 & 3.35 & 157.86 & 4 & 4 & 12.9 \\
\hline Hungary & 8.51 & 3.54 & 27.51 & 1 & 3 & 8.1 \\
\hline India & 6.06 & 5.98 & 26.16 & 2 & 0 & 43.1 \\
\hline Indonesia & 6.95 & 3.11 & 40.09 & 2 & 3 & 126.5 \\
\hline Ireland & 10.05 & 8.57 & 88.27 & 1 & 5 & 21.1 \\
\hline Israel & 9.72 & 3.78 & 78.88 & 3 & 4 & 22.1 \\
\hline Italy & 9.91 & 1.89 & 66.65 & 2 & 6 & 17.6 \\
\hline Japan & 10.69 & 1.19 & 194.44 & 2 & 6 & 8.6 \\
\hline Malaysia & 8.42 & 5.35 & 141.9 & 3 & 6 & 20.2 \\
\hline Mexico & 8.16 & 2.89 & 23.39 & 0 & 6 & 20 \\
\hline Morocco & 7.22 & 3.53 & 50.76 & 1 & 2 & 17.7 \\
\hline Netherlands & 10.28 & 2.85 & 118.52 & 3 & 5 & 17 \\
\hline New Zealand & 9.76 & 3.36 & 105.35 & 4 & 5 & 4.8 \\
\hline Norway & 10.52 & 3.39 & 77.47 & 2 & 5 & 4.2 \\
\hline Oman & 8.68 & 3.66 & 36.4 & 0 & 0 & 10 \\
\hline Panama & 8.09 & 3.25 & 87.25 & 4 & 5 & 37 \\
\hline Poland & 8.26 & 5.07 & 23.58 & 1 & 4 & 8.7 \\
\hline Portugal & 9.38 & 2.99 & 104.75 & 1 & 5 & 17.5 \\
\hline Romania & 7.33 & 1.47 & 8.96 & 1 & 3 & 12.4 \\
\hline Singapore & 10.15 & 5.78 & 114.45 & 3 & 4 & 9 \\
\hline Slovakia & 8.31 & 4.3 & 46.09 & 2 & 3 & 15 \\
\hline Slovenia & 9.27 & 4.07 & 32.32 & 3 & 3 & 16.3 \\
\hline South Africa & 8.29 & 2.87 & 126.68 & 3 & 5 & 11.5 \\
\hline South Korea & 9.44 & 5.8 & 79.38 & 3 & 5 & 5.4 \\
\hline Spain & 9.7 & 3.22 & 88.85 & 2 & 6 & 14.1 \\
\hline Sweden & 10.32 & 3.06 & 92.31 & 1 & 4 & 5.9 \\
\hline Switzerland & 10.72 & 1.23 & 166.01 & 1 & 5 & 5.2 \\
\hline Taiwan & 9.55 & 4.84 & . & 2 & 5 & 7.7 \\
\hline Thailand & 7.95 & 3.22 & 130.66 & 2 & 5 & 13.4 \\
\hline Tunisia & 7.73 & 4.46 & 66.48 & 0 & 2 & 12 \\
\hline Turkey & 7.97 & 2.5 & 20.93 & 2 & 4 & 12.5 \\
\hline United Kingdom & 9.95 & 2.88 & 124.34 & 4 & 6 & 15.7 \\
\hline USA & 10.3 & 3.31 & 211.25 & 1 & 6 & 7.5 \\
\hline Average middle-income countries & 8.08 & 3.82 & 55.67 & 1.7 & 3.9 & 22.04 \\
\hline Average high-income countries & 10.10 & 3.25 & 104.05 & 2.1 & 4.9 & 11.28 \\
\hline Average (total) & 9.13 & 3.53 & 80.37 & 1.9 & 4.4 & 16.44 \\
\hline
\end{tabular}




\section{Table 4: Correlation Matrix}

See Table 1 for complete variable definitions. P-values are shown in parentheses. Asterisks, *,**, and $* * *$, indicate significance at the $10 \%, 5 \%$, and $1 \%$ level, respectively.

\section{LGDPPC $_{t-1}$ GDPPC $_{t-1} \quad$ DC_GDP $_{t-1}$ CreditorRts $\quad$ CreditInfo}

$\begin{array}{lll}\text { GDPPC }_{\mathbf{t}-1} & -0.0877^{*} & \\ & 0.0657 & \\ & & \\ & & \\ \text { DC_GDP } & & \\ & 0.5516^{* * *} & -0.0825^{*} \\ & 0.0000 & 0.0909\end{array}$

$\begin{array}{llllll}\text { CreditorRts } & 0.1967^{* * *} & 0.0117 & 0.3304^{* * *} & & \\ & 0.0005 & 0.8054 & 0.0000 & & \\ \text { CreditInfo } & 0.5128^{* * *} & -0.1204^{* * *} & 0.4269^{* * *} & 0.2795^{* * *} & \\ & 0.0000 & 0.0123 & 0.0000 & 0.0000 & \\ & & & & \\ \text { Enforce_Debt } & -0.4783^{* * *} & 0.0400 & -0.2305^{* * *} & 0.0280 & -0.2152^{* * *} \\ & 0.0000 & 0.2646 & 0.0000 & 0.5452 & 0.0000\end{array}$




\section{Table 5: The Determinants of Factoring}

See Table 1 for complete variable definitions. The dependent variable is the ratio of total factoring turnover to GDP. T-statistics are shown in parentheses. Asterisks, *,**, and ***, indicate significance at the $10 \%, 5 \%$, and $1 \%$ level, respectively.

\begin{tabular}{|c|c|c|c|c|c|c|}
\hline & (1) & (2) & (3) & (4) & (5) & (6) \\
\hline LGDPPC $_{\mathrm{t}-1}$ & $\begin{array}{c}0.60 * * * \\
(2.64)\end{array}$ & $\begin{array}{l}0.72 * * * \\
(10.13)\end{array}$ & $\begin{array}{c}0.52 * * * \\
(6.28)\end{array}$ & $\begin{array}{c}0.73 * * * \\
(7.75)\end{array}$ & $\begin{array}{c}0.63 * * * \\
(7.63)\end{array}$ & $\begin{array}{c}0.63 * * * \\
(2.48)\end{array}$ \\
\hline GDPG1 $1_{t-1}$ & $\begin{array}{c}0.02 \\
(1.63)\end{array}$ & $\begin{array}{l}0.05^{*} \\
(2.10)\end{array}$ & $\begin{array}{c}0.07 * * * \\
(2.70)\end{array}$ & $\begin{array}{l}0.05^{* *} \\
(2.16)\end{array}$ & $\begin{array}{c}0.64 * * * \\
(2.85)\end{array}$ & $\begin{array}{l}0.29 * * \\
(1.99)\end{array}$ \\
\hline DC_GDP ${ }_{t-1}$ & $\begin{array}{c}-0.01 \\
(-0.55)\end{array}$ & $\begin{array}{l}-0.00 \\
(-0.27)\end{array}$ & $\begin{array}{c}-0.02 \\
(-1.24)\end{array}$ & $\begin{array}{c}-0.00 \\
(-0.17)\end{array}$ & $\begin{array}{l}-0.00 \\
(-0.79)\end{array}$ & $\begin{array}{l}-0.00 \\
(-0.65)\end{array}$ \\
\hline CreditorRts & & $\begin{array}{c}0.04 \\
(0.34)\end{array}$ & & & $\begin{array}{l}-0.03 \\
(-0.27)\end{array}$ & $\begin{array}{l}-0.07 \\
(-0.24)\end{array}$ \\
\hline CreditInfo & & & $\begin{array}{c}0.33 * * * \\
(5.44)\end{array}$ & & $\begin{array}{c}0.34 * * * \\
(5.56)\end{array}$ & $\begin{array}{c}0.39 * * * \\
(2.61)\end{array}$ \\
\hline Enforce_Debt & & & & $\begin{array}{l}0.01^{*} \\
(1.90)\end{array}$ & $\begin{array}{l}0.01^{*} \\
(1.64)\end{array}$ & $\begin{array}{c}0.01 \\
(0.83)\end{array}$ \\
\hline Constant & $\begin{array}{c}-2.59 * * * \\
(-3.33) \\
\end{array}$ & $\begin{array}{c}-4.58 * * * \\
(-7.48) \\
\end{array}$ & $\begin{array}{c}-4.38 * * * \\
(-7.35) \\
\end{array}$ & $\begin{array}{c}-5.02 * * * \\
(-6.89) \\
\end{array}$ & $\begin{array}{c}-4.29 * * * \\
(-6.91) \\
\end{array}$ & $\begin{array}{c}-6.22 * * * \\
(-3.01) \\
\end{array}$ \\
\hline $\begin{array}{c}\text { Country } \\
\text { dummies } \\
\text { Year } \\
\text { dummies }\end{array}$ & $\begin{array}{l}\text { Yes } \\
\text { Yes }\end{array}$ & Yes & Yes & Yes & Yes & No \\
\hline $\begin{array}{l}\text { Observations } \\
\text { Adj. R-Sq. }\end{array}$ & $\begin{array}{l}413 \\
0.88\end{array}$ & $\begin{array}{l}456 \\
0.18\end{array}$ & $\begin{array}{l}404 \\
0.21\end{array}$ & $\begin{array}{l}404 \\
0.18\end{array}$ & $\begin{array}{l}404 \\
0.21\end{array}$ & $\begin{array}{c}46 \\
0.30\end{array}$ \\
\hline
\end{tabular}




\section{Figure 1: The Nafin Factoring Agreement}

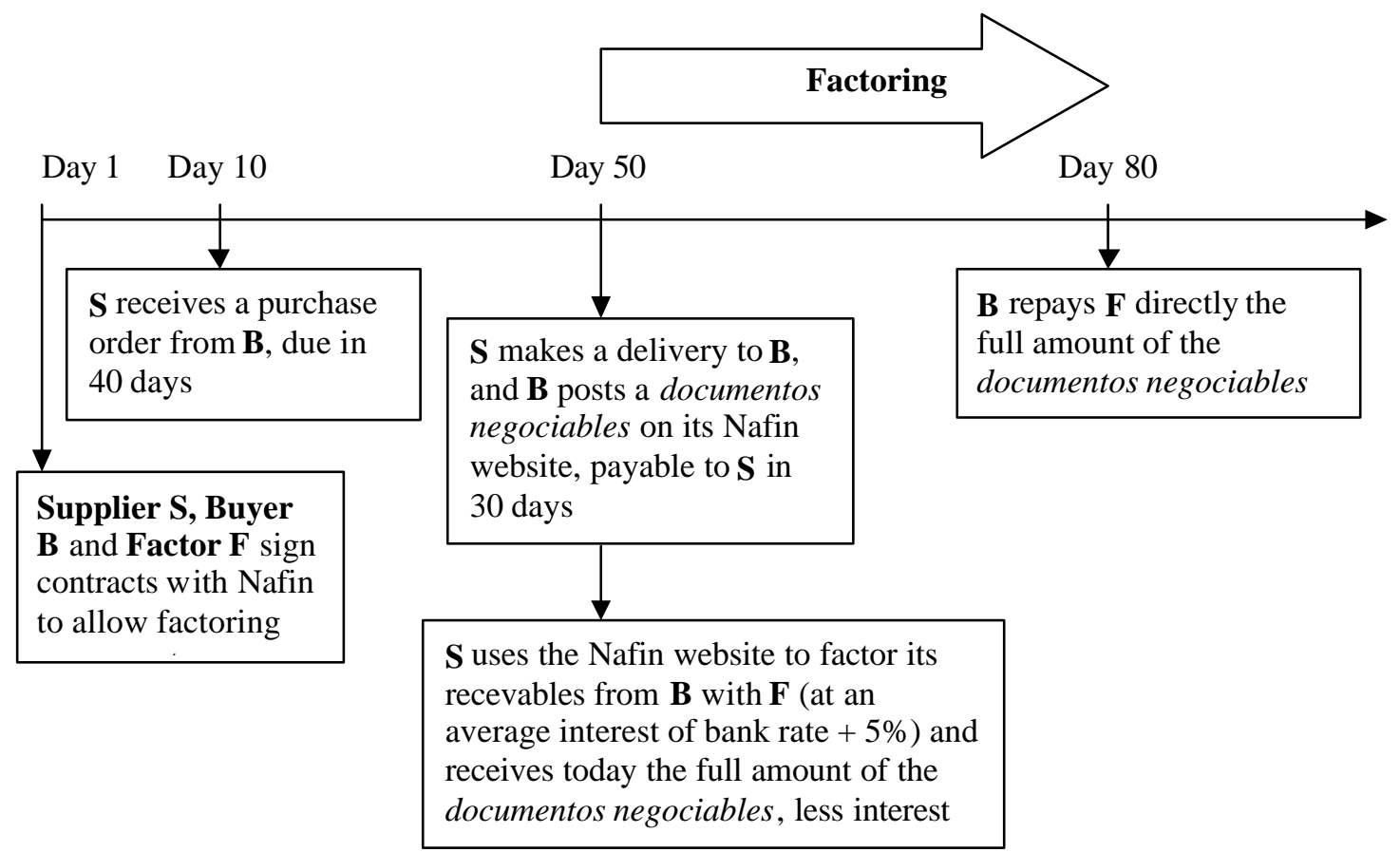


Figure 2: The Nafin Purchase Order Agreement

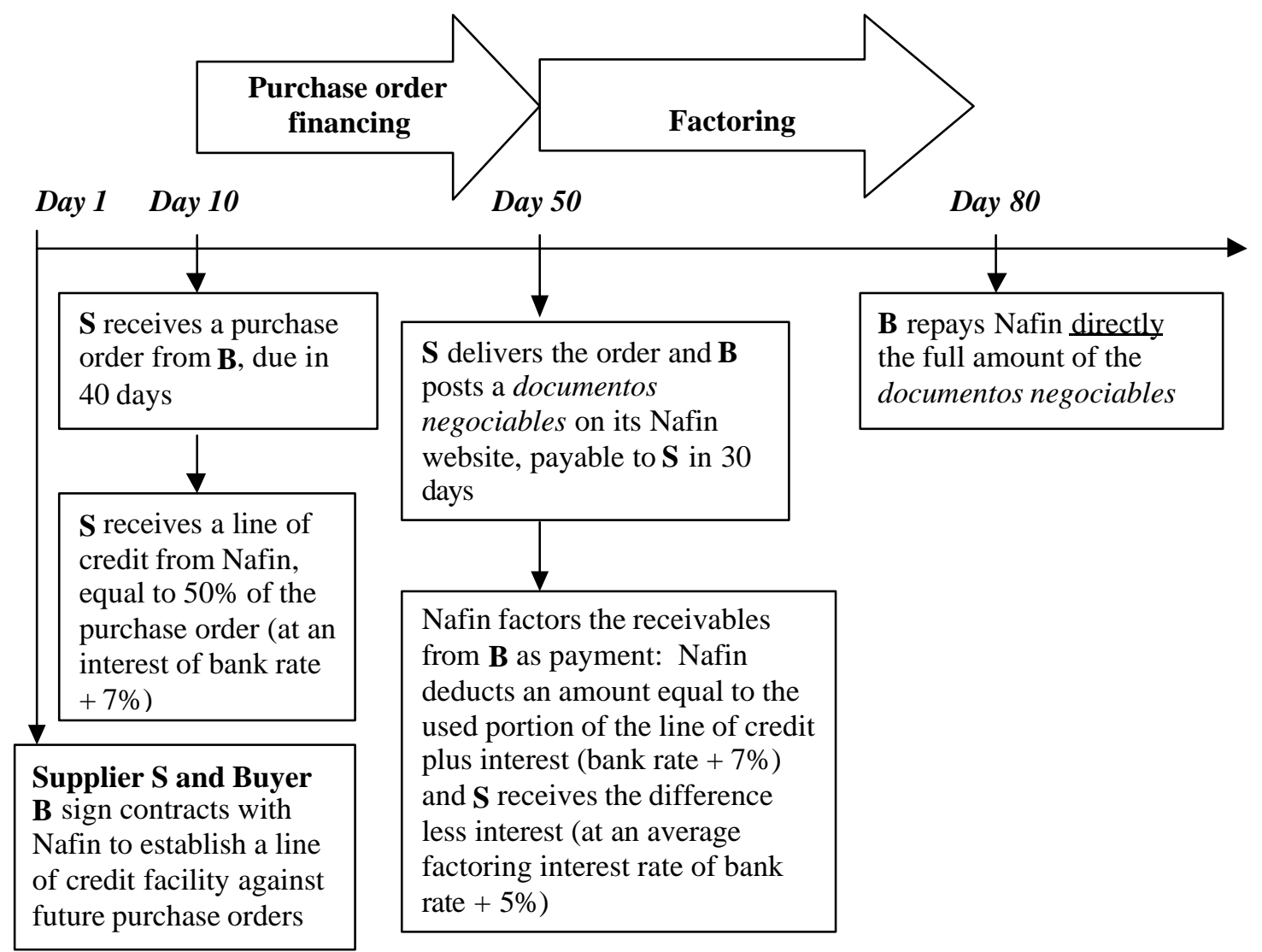

